\title{
IMAGE
}

\section{Insights Figure for "Differential cell proliferation and cell death during the urethral groove formation in guinea pig model"}

\author{
Shanshan Wang ${ }^{1}$ and Zhengui Zheng (D) ${ }^{1}$ \\ Pediatric Research (2019) 86:546; https://doi.org/10.1038/s41390-019-0462-0
}

Urethral canal (uc) movement and urethral groove (ug) formation processes in guinea pig genital tubercle (gt) development. At embryonic day (E) 23, UC located in dorsal region, Shh gene expressed in urethral epithelium (orange), and separated the ectoderm derived epithelium (blue). Only cell proliferation (green dots), was detected in urethra. At E24, outer layers cell proliferation increased epithelial layers, programmed cell death (purple dots) in inner layers enlarged UC in ventral region. At E26, differential cell proliferation and cell death in urethral epithelium were involved in dorsal-toventral movement of UC and the whole urethra. At E27, UC moved to the ventral edge of
GT, programmed cell death in ventral most region was important in ventral urethral opening. Programmed cell death at urethral opening region led to enlarged opening and formed urethral groove at E28. Differential cell proliferation and cell death may be involved in future tubular urethral formation as well

\section{REFERENCE}

Wang, S., Zheng, Z. Differential cell proliferation and cell death during the urethral groove formation in guinea pig model. Pediatr Res. (2018). https://doi.org/10.1038/ s41390-018-0236-0 [Epub ahead of print].

Urethral canal (uc) movement and urethral groove (ug) formation processes in guinea pig genital tubercle (gt) development

UC located in dorsal at E23, Shh expressed in urethral epithelium (orange), and separated the ectoderm derived epithelium (blue). Only cell

proliferation (green dots), was detected in urethra.
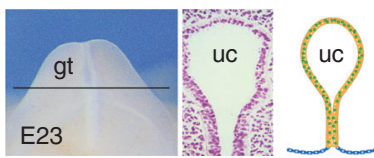

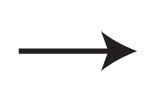

Programmed cell death at urethral opening region led to enlarged opening and formed urethral groove at E28. Differential cell proliferation and cell death may be involved in future tubular urethral formation as well.
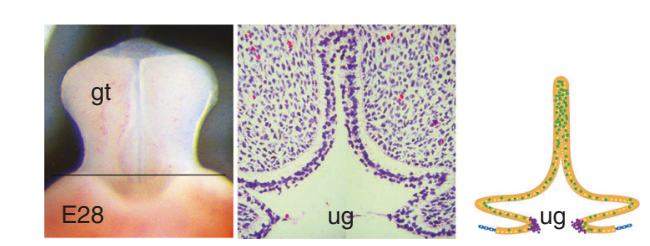

Outer layers cell proliferation increased epithelial layers, programmed cell death (purple dots) in inner layers enlarged UC in ventral region.
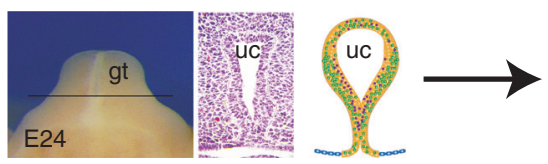

Differential cell proliferation and cell death in urethral epithelium were involved in dorsal-toventral movement of UC and the whole urethra.
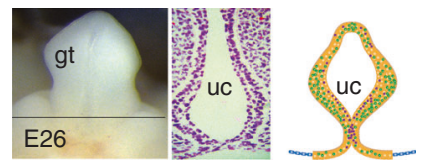

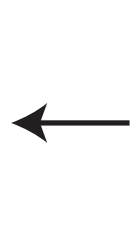

At E27, UC moved to the ventral edge of GT, programmed cell death in ventral most region was important in ventral urethral opening.
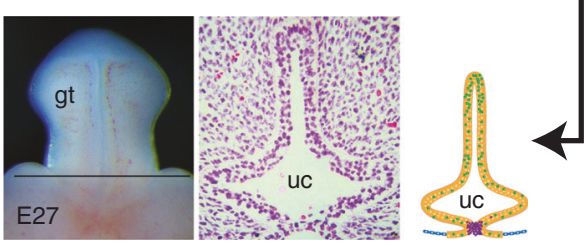

'Department of Physiology, School of Medicine, Southern Illinois University Carbondale, Carbondale, IL 62901, USA Correspondence: Zhengui Zheng (zzheng57@siumed.edu)

Received: 17 May 2019 Accepted: 29 May 2019

Published online: 18 June 2019 